\title{
The Economics of Reverse Osmosis Desalination Projects
}

\author{
Mark Wilf ${ }^{1, *}$ and Raphael Semiat ${ }^{2}$ \\ ${ }^{1}$ RO Technology, California, USA \\ ${ }^{2}$ Chem. Eng. Faculty, Technion IIT, Israel
}

\begin{abstract}
Desalination applications based on reverse osmosis (RO) technology today comprise over $50 \%$ of the capacity of all desalination systems worldwide and represent $75-85 \%$ of new desalination projects being implemented. The major reason for the shift in desalination projects to RO technology is the high energy efficiency of the RO process. There are three major application categories of large capacity, RO-based desalination projects: brackish RO; advanced municipal wastewater reclamation; and seawater RO. In the two first categories (brackish RO and wastewater reclamation), the systems' configuration and equipment components are well defined. Therefore, project costs and operating expenses are fairly predictable. In seawater $\mathrm{RO}$ desalination systems, the RO process configuration is also very similar; however, some variability exists regarding the configuration of seawater water delivery and feed water pretreatment. The rest of the system's components and system operation methods are very uniform. However, an evaluation of published cost data of medium- to large-scale water $\mathrm{RO}$ desalination projects illustrates significant variability in costs of desalination systems.
\end{abstract}

This paper will analyze current economic conditions of seawater desalination, and highlight the limitations and possibilities of additional improvements of the economics of the SWRO desalination process.

Keywords: Desalination, Reverse osmosis, energy, investment, cost.

\section{INTRODUCTION}

The variability in the desalination systems process is especially noticeable among RO seawater desalination systems built at different geographic locations. In some cases, the difference in product water cost produced by plants of a similar capacity but located in different countries can exceed $100 \%$. The existence of such a great difference is very noticeable, considering that the desalination process, plant configuration and construction materials of seawater RO (SWRO) equipment are quite similar for the majority of plants.

The critical components of RO desalination plants membrane elements and pressure vessels - are standardized with respect to configuration, dimensions and capacity, and have similar market prices worldwide. All new SWRO desalination systems utilize similar types of high-pressure pumps and energy recovery devices, which brings energy usage to a similar range of $3-4 \mathrm{KWh} / \mathrm{m}^{3}$. This suggests that the difference in economics of SWRO desalination projects is the result of localized factors such as local labor rates, cost of construction materials and site-specific environmental regulations.

To overcome issues of high local project cost components, it has become more common to construct the major components of a desalination system at

*Address correspondence to this author at the RO Technology, California, USA; Tel: (+1) 858444 7334; Fax: (+1) 8584523805 ;

E-mail: mark.wilf@ROtechnology.net locations having low labor rates and bring the assembled subsystem (via maritime shipment) to the desalination plant site for the final integration. An additional approach for reducing product water cost is to optimize the RO membrane unit configuration through the selection of membrane elements. The objective is to reduce feed pressure while still producing the required permeate quality. These efforts are leading to a shift in membrane element selection to the utilization of higher permeability membranes and applying a partial two-pass system configuration as required. This approach is encountering limitations inherent to high permeability membranes: unacceptably high permeate salinity and/or concentrate pressure converging to the level of osmotic pressure of the concentrate, i.e., possible operation at negligible net driving pressure (NDP) at the concentrate end of the RO membrane unit. Therefore, an additional reduction in the power requirement of the $\mathrm{RO}$ process through a reduction in feed pressure is not very likely. Still, very high permeability SWRO membrane elements can be utilized to reduce the cost of the RO system while producing permeate of acceptable quality. In this system design approach, the very high permeability membrane elements will be utilized for operation at elevated permeate flux and enable a reduction in size of RO membrane units.

Water desalination techniques are possible solutions for water needs around the world. The main reasons for water deficiency in many locations globally are:

(c) 2016 Lifescience Global 
Population growth

Increased standards of living in many places around the world

Droughts and over-use of available natural water causing significant inefficient use of available water

\section{Pollution of large natural water resources}

Desalination in different forms can solve a significant part of the problems. However, it is not a single solution and others should be included, especially educating towards water savings, making better use of desalination in agriculture, and significantly reducing environmental pollution coming from wastewater from urban and industrial sources that are affecting our water sources.

This paper concentrates on current membrane desalination processes, in particular, the reverse osmosis process.

\section{ENERGY CONSUMPTION IN DESALINATION PROCESSES}

Among commercial desalination technologies, reverse osmosis is the most energy efficient method of producing potable quality water. The difference in energy requirements between evaporation processes and RO-based desalination is so significant that the majority of new systems being constructed utilize RO technology and over $50 \%$ of desalination plants worldwide use the RO process. Since energy is one of the highest water cost components related to desalination processes, Figure 1 presents the different energy consumptions used for different industrial processes and Figure 2 presents the energy needed for the RO process and the auxiliary energy needs for different RO processes. Indeed, brackish water needs the lowest energy of all processes, yet the amount of brackish water available for desalination is limited and cannot be implemented in some locations due to the limitation of concentrate disposal. The reclamation of municipal wastewater for indirect potable use is steadily growing. Wastewater for advanced reclamation is available close to all large urban centers. However, indirect potable use requires specific configuration of underground aquifers, which are not available in all locations. Direct potable use of reclaimed wastewater faces significant problems of public acceptance. There is no limitation in using seawater for desalination, however, for acceptable economics and practical convenience of seawater supply and concentrate disposal, SWRO plants must be located at a short distance from the seashore.

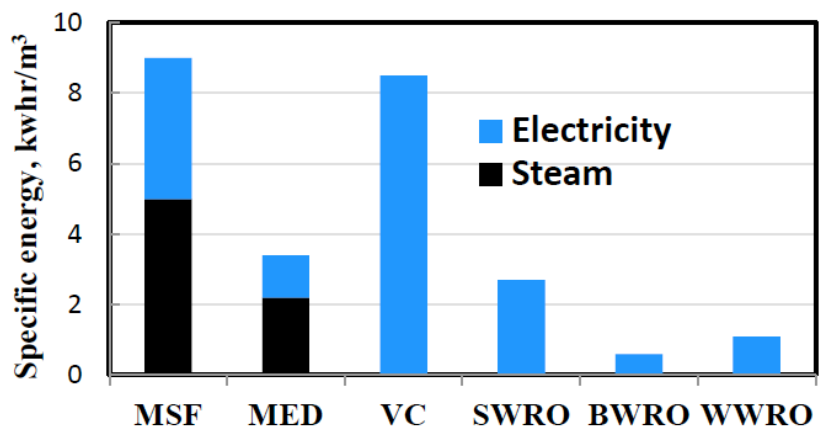

Figure 1: Energy requirements of various commercial desalination technologies. MSF - Multi Stage Flash, MED Multi Effect Distillation, VC - Vapor Compression.

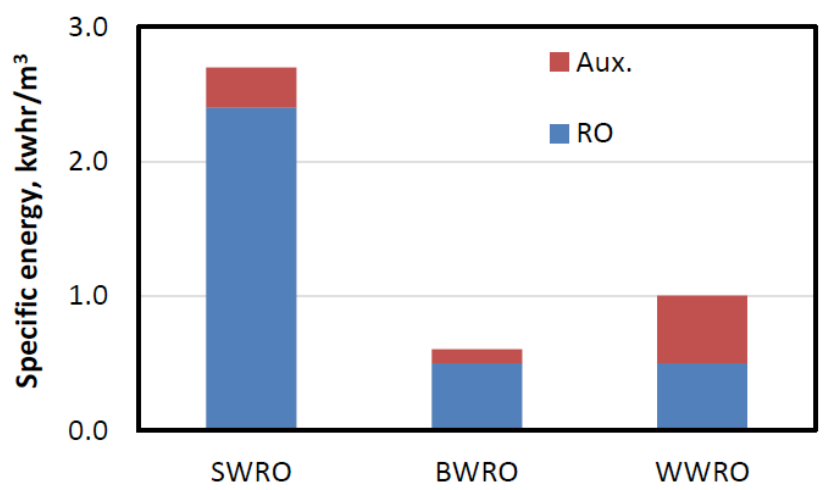

Figure 2: Energy requirements of desalination processes based on RO technology.

Three major RO-based desalination processes include:

\section{$>\quad$ Seawater RO (SWRO) \\ $>\quad$ Brackish water RO (BWRO) \\ $>\quad$ Wastewater reclamation utilizing $\mathrm{RO}(\mathrm{WWRO})$}

The energy requirement of SWRO processes, without the energy required for pumping product water, is below $3 \mathrm{KWh} / \mathrm{m}^{3}$. The energy requirements of BWRO and WWRO processes are similar for the RO section of the process, about $0.5 \mathrm{KWh} / \mathrm{m}^{3}$. The additional energy requirement of the WWRO process is for the membrane filtration pretreatment process and the advanced oxidation process (AOP).

The energy requirement of the SWRO process may increase by up to about $1 \mathrm{KWh} / \mathrm{m}^{3}$ if long-distance pumping of product water is needed. Additional energy for the BWRO process is required if the recovery of the 
RO system is relatively low (due to the high scaling potential of RO concentrate), and the concentrated brine must be pumped a long distance for disposal. This is usually not the case for WWRO since WWRO plants are located close to wastewater treatment plants where $\mathrm{RO}$ concentrate is returned for disposal with the wastewater treatment plant outfall.

\section{APPLICATIONS OF RO DESALINATION PROCESSES}

Table 1 represents the different applications for the three $\mathrm{RO}$ based desalination processes. In all three RO applications - SWRO, BWRO and WWRO - the process is well established and very reliable. Due to the nature of the process that, in addition to permeate stream, also produces a high salinity concentrate stream that must be disposed of, the preferred location for desalination plants are close to the feed water source and to the concentrate disposal location. For brackish and wastewater RO applications, the concentrate stream represents about $20 \%$ of the feed water stream. In the case of SWRO, the concentrate stream flow rate represents $50 \%$ of the feed flow.

The obstacles for implementing various RO-based processes vary with application, but are not related to any technical problems. For BWRO, the least expensive and lowest energy desalination process, the main obstacles are limited availability of brackish water sources and the possibility of RO concentrate disposal.

For WWRO applications, the major obstacle is public reluctance to accepting direct reuse of advanced treated municipal effluent. On the other hand, people accept the supply of drinking water from river water, even knowing that at the upstream location, municipal wastewater is discharged to the river (it is estimated that Thames River water is processed 2-3 times through the human body before reaching London).

The major obstacles for SWRO are the high energy requirement and environmental concerns related to pumping large volumes of seawater to the RO plant and the return of concentrate stream of twice the salinity of the original seawater.

Table 2 represents the different parameters exists in the different $\mathrm{RO}$ based desalination processes. The critical process components of $\mathrm{RO}$ desalination applications are $\mathrm{RO}$ membranes that provide required salinity reduction. Both BWRO and WWRO process water of low salinity. Therefore, they utilize similar membrane elements and feed pressure, and the

Table 1: Major Characteristics of RO-Based Desalination Processes

\begin{tabular}{|c|c|c|c|}
\hline Application & Brackish RO & Wastewater Reclamation & Seawater RO \\
\hline Development stage & $\begin{array}{l}\text { Mature, very reliable process } \\
\text { of new water supply }\end{array}$ & $\begin{array}{c}\text { Mature, very reliable process of new } \\
\text { water supply }\end{array}$ & $\begin{array}{c}\text { Mature, very reliable process of } \\
\text { new water supply }\end{array}$ \\
\hline Feed water source & Brackish wells & $\begin{array}{l}\text { Secondary effluent from sanitation } \\
\text { district }\end{array}$ & Ocean intake \\
\hline Preferable location & Close to brackish well field & $\begin{array}{c}\text { Vicinity of wastewater reclamation } \\
\text { plant }\end{array}$ & Seashore \\
\hline $\begin{array}{l}\text { Major obstacles with wide- } \\
\text { scale implementation }\end{array}$ & $\begin{array}{l}\text { Limited availability of brackish } \\
\text { water; concentrate disposal }\end{array}$ & Public acceptance of direct reuse & $\begin{array}{l}\text { Permits related to environmental } \\
\text { concerns; high energy requirement }\end{array}$ \\
\hline
\end{tabular}

Table 2: Membrane Parameters in RO-Based Desalination Processes

\begin{tabular}{|c|c|c|c|}
\hline Application & Brackish RO & Wastewater Reclamation & Seawater RO \\
\hline Feed salinity range, ppm TDS & $1,200-10,000$ & $800-2,000$ & $32,000-45,000$ \\
\hline Representative average osmotic pressure, bar (psi) & $6(85)$ & $3(45)$ & $44(640)$ \\
\hline System recovery rate, $\%$ & $70-85$ & $75-85$ & $40-50$ \\
\hline Number of desalination stages & 2 & $2-3$ & 1 \\
\hline Membrane water permeability, $1 / \mathrm{m}^{2} / \mathrm{hr} / \mathrm{bar}$ (gfd/psi) & $5-8(0.2-0.3)$ & $5-8(0.2-0.3)$ & $1-1.5(0.04-0.06)$ \\
\hline Nominal salt rejection, \% & $99.0-99.7$ & $99.0-99.7$ & $99.75-99.85$ \\
\hline Average permeate flux rate range, $1 / \mathrm{m}^{2} / \mathrm{hr}$ (gfd) & $22-27(13-16)$ & $17-20(10-12)$ & $13.6-17.0(8-10)$ \\
\hline Representative feed pressure range, bar (psi) & $10-15(150-220)$ & $8-12(120-180)$ & $55-70(800-1,000)$ \\
\hline
\end{tabular}


energy requirements of both processes are similar. The SWRO process treats feed water of significantly higher salinity, therefore requiring denser membranes (lower water permeability), and the required feed pressure is much higher than in BWRO or WWRO.

\section{SCHEMATIC CONFIGURATIONS OF RO PROCESSES}

Figure 3 represents the schematic configuration of BWRO desalination system. Feed water to a BWRO system is supplied from wells. The well water is characterized by a low concentration of suspended solids. Pretreatment is limited to the addition of acid and/or scale inhibitors, followed by cartridge filtration. A high-pressure pump pumps brackish water to the RO membrane train. The permeate water usually has a low $\mathrm{pH}$ and must be stabilized by removing $\mathrm{CO}_{2}$ and adding caustic to prevent corrosion of the water distribution network. Concentrate from brackish RO plants is disposed mainly through deep well injection.

Figure 4 represents the schematic configuration of a wastewater reclamation system utilizing the $\mathrm{RO}$ process (2). The RO section of a WWRO plant is similar to a BWRO plant. However, the feed water to a WWRO plant is secondary effluent of high concentration of soluble organics and colloidal matter. Pretreatment in a WWRO plant consists almost universally of the membrane filtration step, followed by acidification and the addition of a scale inhibitor. In addition, in order to prevent biological activity in ROI membranes, feed water contains a low concentration of chloramines. After the RO step, the product water is treated in the advanced oxidation process (AOP) to reduce the concentration of micro pollutants, such as traces of pharmaceutical and personal care products.
The AOP process consists of UV radiation combined with the addition of hydrogen peroxide. The product water is also stabilized by removal of $\mathrm{CO}_{2}$ and the addition of caustic.

Figure 5 represents the schematic configuration of a seawater RO desalination system (1). SWRO plants treat water from open surface intakes. Seawater, in addition to high salinity, is also characterized by a high concentration of suspended solids and the periodic presence of algal bloom. For this reason, the feed water pretreatment process consists of a filtration step, sometimes augmented by dissolved air flotation (DAF). Due to high feed water salinity, the feed pressure to RO membranes is in the range of 55-70 bar. Frequently, the permeate salinity produced in the SWRO membrane unit is not sufficiently low, and additional $\mathrm{RO}$ processing using the brackish RO membrane unit is applied. This second pass process is usually applied to part of permeate produced by pass 1 , and two permeates from passes 1 and 2 are blended together. The product water from the SWRO unit is also very corrosive and is stabilized by the addition of hardness and alkalinity. All modern SWRO plants utilize energy recovery devices to reduce energy consumption.

\section{WATER COST}

Figure 6 shows the water cost changes between 1988-2010 in large SWRO projects (3). Figure 7 demonstrate recent water costs of large plants. The production in SWRO plants shows a clear trend of price reduction. The driving force for this price reduction was a reduction in energy requirements through the introduction of efficient energy recovery devices, the introduction of higher permeability, and high rejection

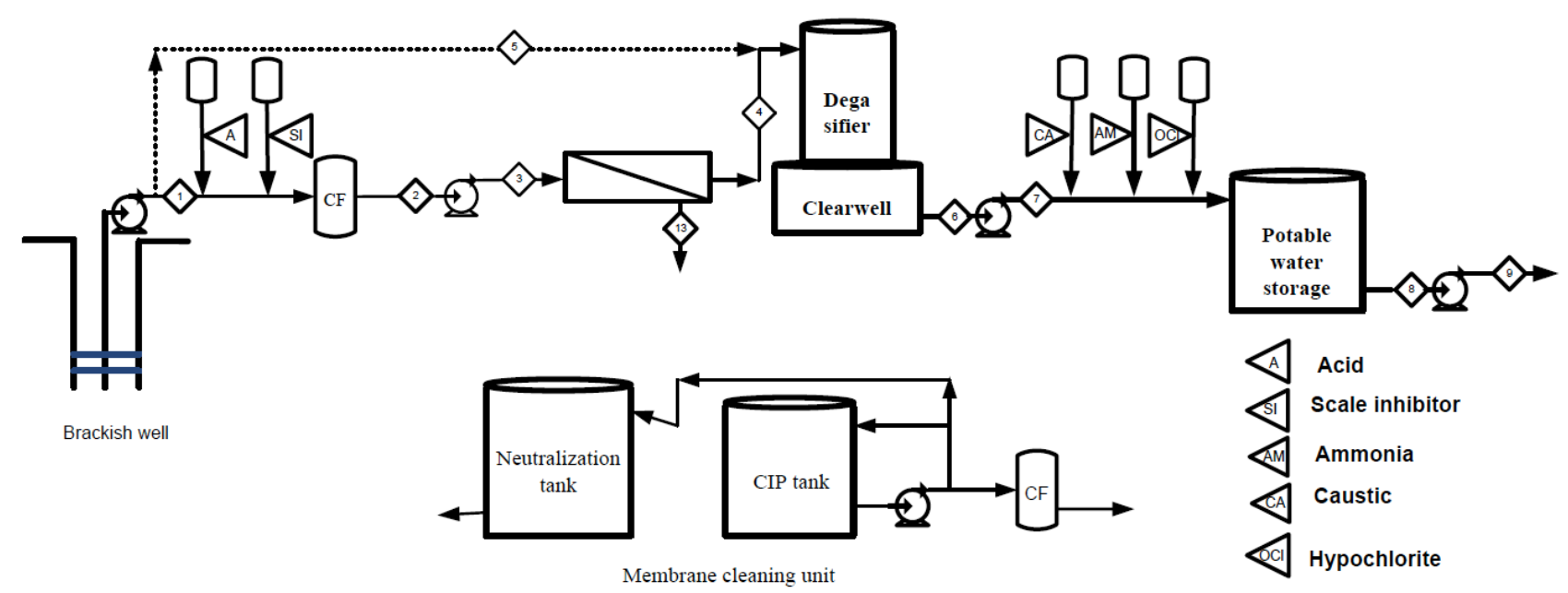

Figure 3: Schematic configuration of brackish water RO desalination system (1). 


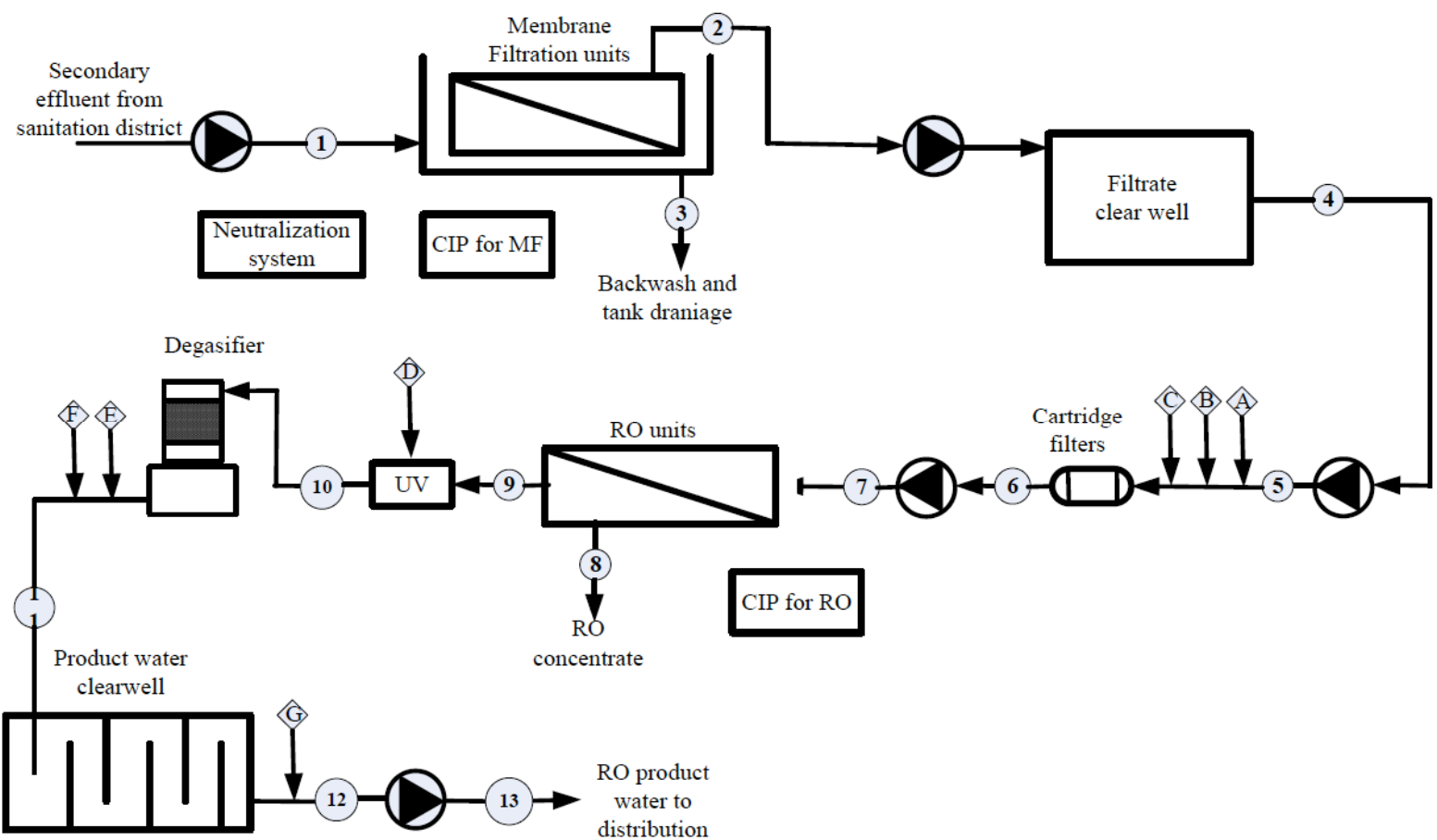

Figure 4: Schematic configuration of a wastewater reclamation system utilizing the RO process (2).

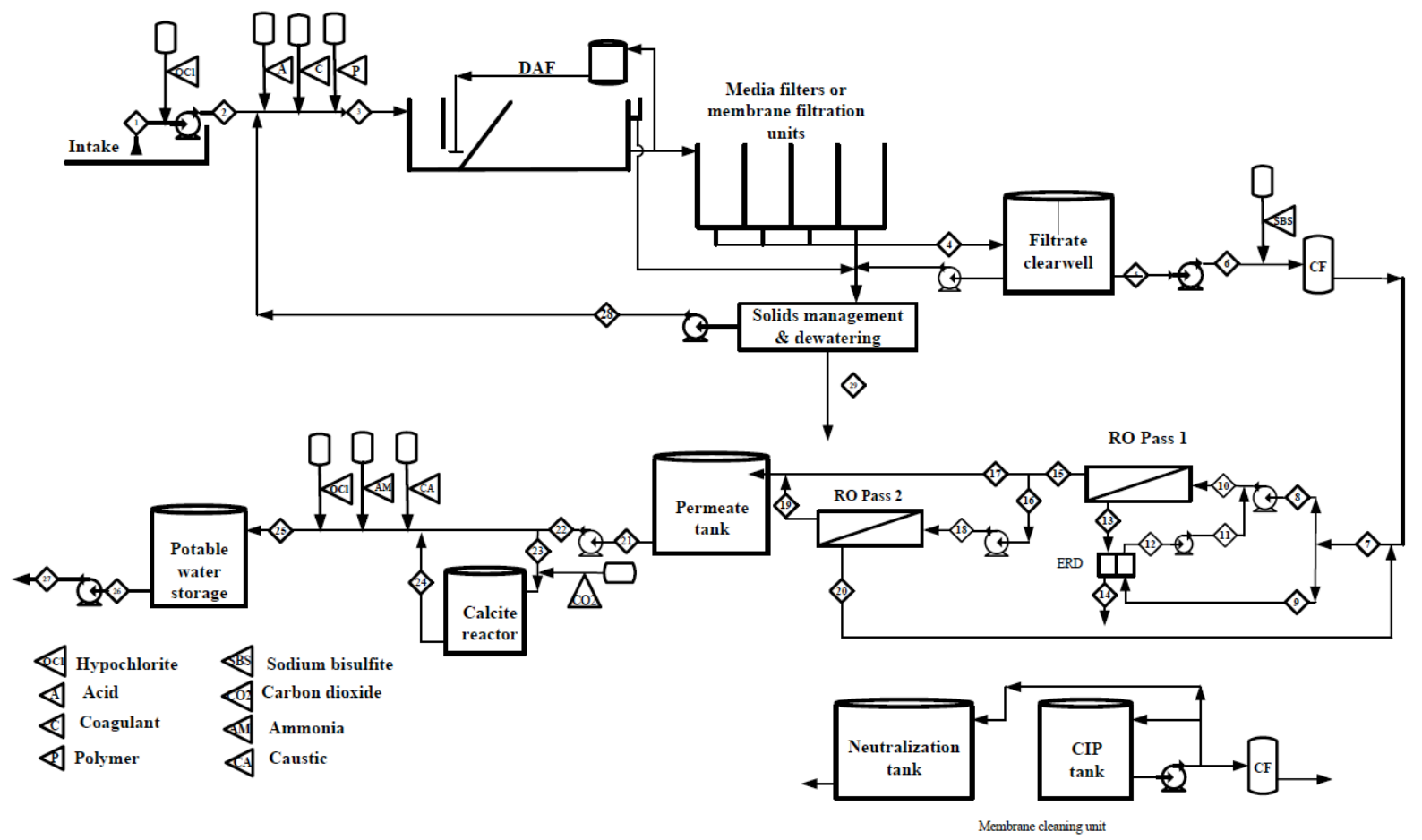

Figure 5: Schematic configuration of a seawater RO desalination system (1).

RO membranes that enable the operation of a SWRO plant at higher recovery rates and reduced feed pressure. An additional improvement in the process and equipment was gradually introduced by EPCs as competition increased with project implementation moving to Design-Build-Operate (DBO) projects delivery.
This trend of price reduction has been reversed recently. In Europe, the Middle East and the Pacific Rim, the water process has remained low. In Australia and California, the water prices from SWRO plants are much higher than from SWRO plants built recently in other locations. 


\section{Large seawater RO systems - water price}

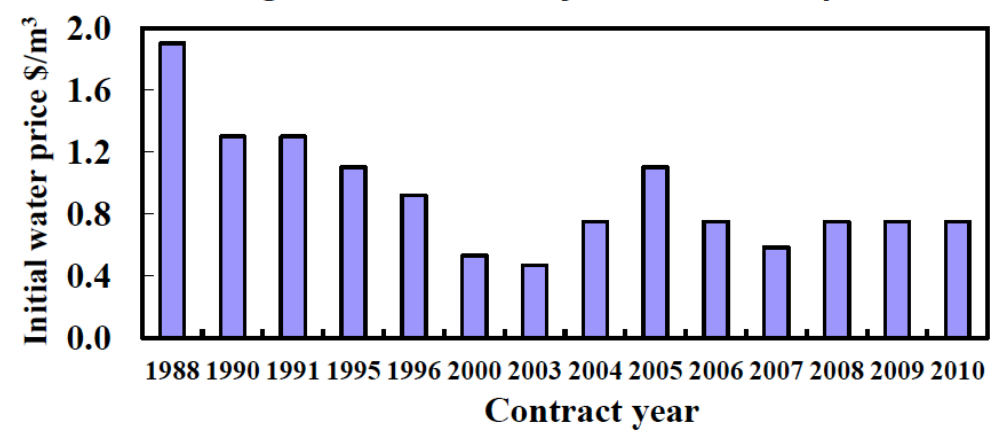

Figure 6: Water prices from large SWRO projects (3).

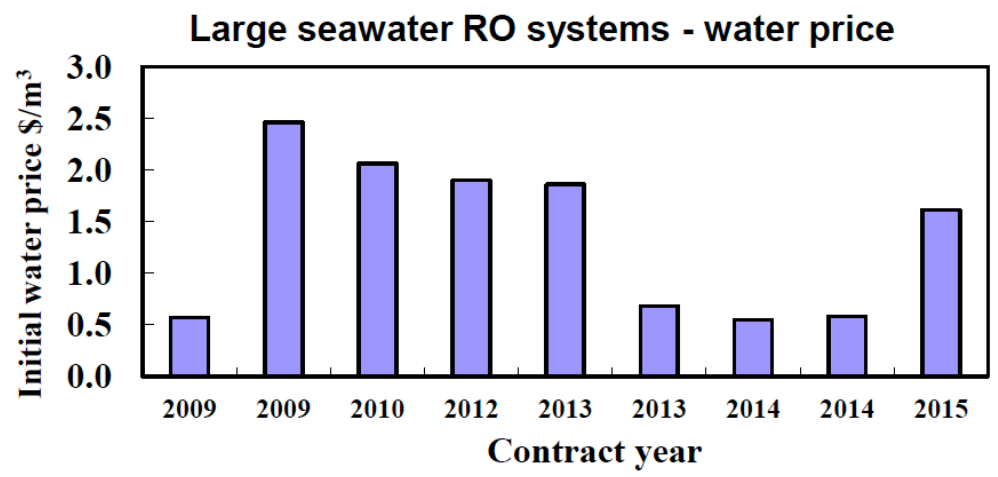

Figure 7: Water prices from recent large SWRO projects (3).

The SWRO plant in Australia and the plant that recently started operation in California are configured in a similar manner and utilize very similar major equipment and membrane elements. The process parameters are similar, resulting in similar plant operating expenses. The major difference is related to much higher project costs at these two locations. The high project cost can be attributed to the very lengthy project permit process, compliance with strict environmental regulations, and higher labor cost.

Figure 8 represents the components of energy requirements of the different $\mathrm{RO}$ and $\mathrm{NF}$

$$
E_{\text {tot }}=E_{r w}+E_{p r t}+E_{h p}+E_{p r o d}+E_{a u x}
$$

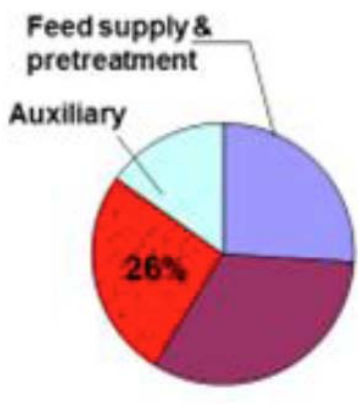

NF

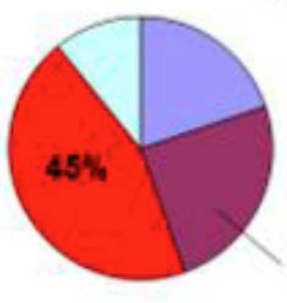

High pressure feed pumping

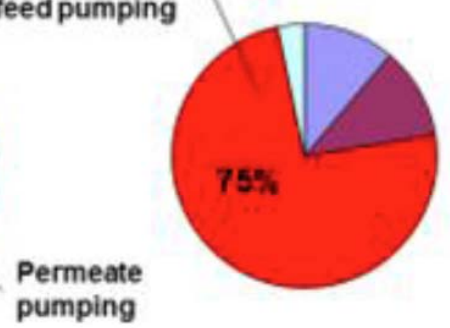

BRO

$$
\begin{gathered}
\text { E } 0.9 \mathrm{kwhr} / \mathrm{m}^{3} \\
\text { (3.4kwhr/kgallon) }
\end{gathered}
$$

SWRO

$$
\begin{gathered}
E \sim 3.1 \mathrm{kwhr} / \mathrm{m}^{3} \\
\text { (11.7 kwhr/kgallon) }
\end{gathered}
$$

Figure 8: Energy requirements of RO and NF desalination processes in different water salinities (1). 


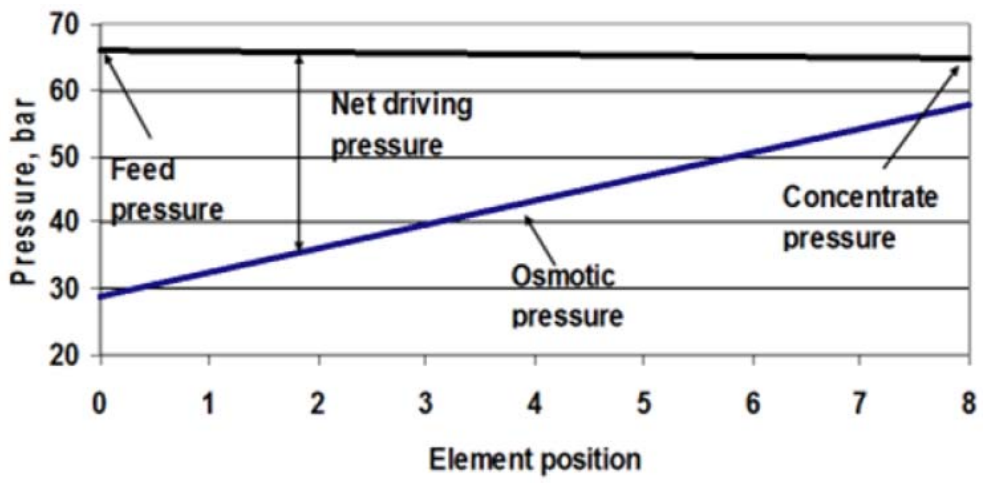

Figure 9: Schematic presentation of osmotic and feed pressure in a seawater RO unit (1).

(Nanofiltration) desalination processes (1). NF may be used with low salt content in the water. Energy usage in the $\mathrm{RO}$ desalination process is a function of feed water salinity, recovery rate, pretreatment process and required pressure for product water distribution.

In SWRO, where the energy usage required by high-pressure feed pumps is the highest, the lower limit of feed pressure is dictated by the osmotic pressure of the concentrate stream. The applied feed pressure must be high enough to provide some driving pressure at the concentrate exit from the SWRO membrane unit. Figure 9 illustrates the changes in osmotic and operation pressure along eight membranes elements.
The net driving force is the difference between operating pressure and increased osmotic pressure.

\section{PERMEABILITY AND REJECTION}

A new type of high permeability membrane has been introduced recently also for SWRO applications. It is clear from water permeability-salt transport relations that for the polyamide membrane barrier, water and salt transport are directly related, as may be seen from Figures $\mathbf{1 0}$ and $\mathbf{1 1}$ for seawater and brackish water, respectively.

For SWRO membranes, the higher permeability membrane that can be operated at lower feed pressure

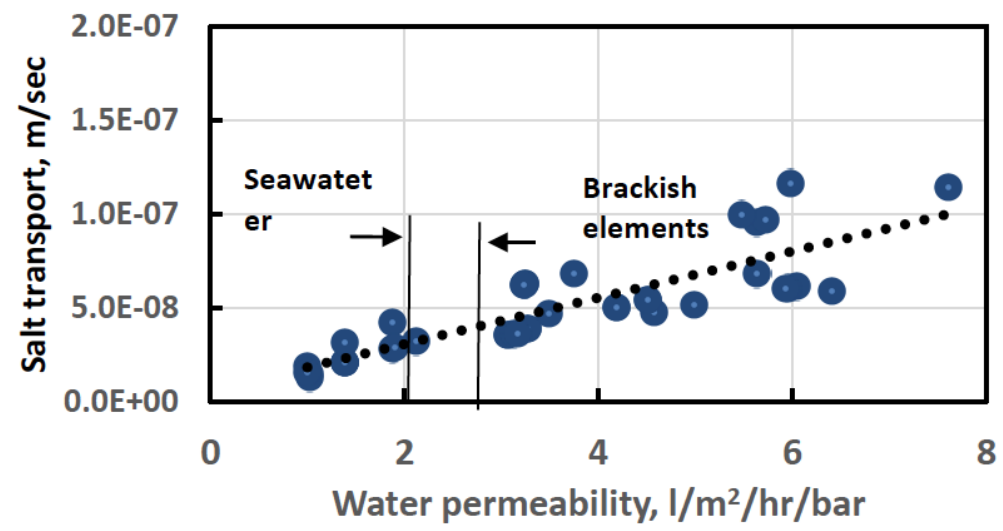

Figure 10: Salt transport vs water permeability of commercial RO membranes (4).

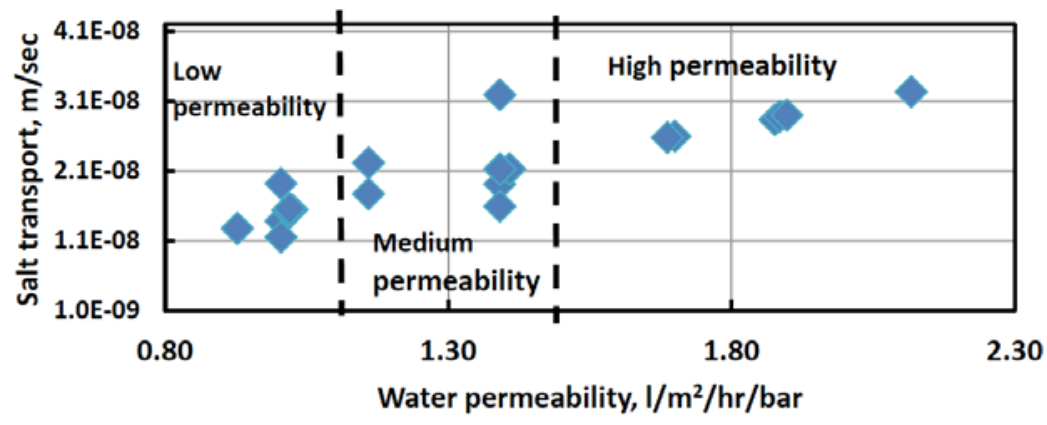

Figure 11: Salt transport vs water permeability of commercial brackish water membranes (4). 
will produce permeate at an increasingly higher permeate salinity. Therefore, in addition to the limitation of osmotic pressure of the concentrate, the additional limit of utilization of high permeability membrane is the increased salinity of product water. Utilization of very high permeability SWRO membrane elements will require increased second pass processing at additional system costs and energy requirements of the second pass $\mathrm{RO}$.

\section{COMPONENTS OF PROJECT CAPITAL COST}

The capital cost distribution in RO-based desalination applications can be summarized as follows:

- $\quad$ Project development cost

- Project preparation (mobilization, bond, insurance)

- Permits

Table 3: Capital Cost Components
- $\quad$ Engineering service

- $\quad$ Direct construction cost

- $\quad$ Project financing cost

- $\quad$ Contingency

Table 3 and Figure 12 illustrate the capital cost components for different RO systems at a capacity of $150,000 \mathrm{~m}^{3} /$ day. As may be seen, the major investment is in the raw water pre-treatment followed by the RO equipment, namely, pumps, membranes, pressure vessels, piping systems for feed, permeate and concentrates. The equipment installation and site work follow. While SWRO and WWRO require greater investment for pretreatment, the highest component in BWRO is the site work.

The differences in operating costs are shown in Table 4 and Figure 13. Here, as expected, electricity is

\begin{tabular}{|c|c|c|c|}
\hline Component (\%) & SWRO & BWRO & WWRO \\
\hline Capacity, $\mathrm{m}^{3} / \mathrm{d}$ & 150,000 & 150,000 & 150,000 \\
\hline Raw water \& pretreatment & 38.4 & 24.6 & 36.5 \\
\hline RO equipment & 19.4 & 25.3 & 20.4 \\
\hline Electric and instrumentation & 4.2 & 4.3 & 2.9 \\
\hline Equipment installation & 12.9 & 10.9 & 11.7 \\
\hline Site work & 18.0 & 28.8 & 22.1 \\
\hline Project management \& commissioning & 7.1 & 6.0 & 6.4 \\
\hline
\end{tabular}

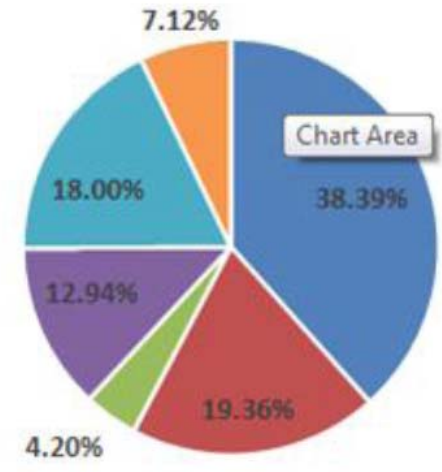

a.

$$
\begin{aligned}
& \text { = Raw water \& pretreatment } \\
& \text { = Electric + instrumentation } \\
& \text { = Site work }
\end{aligned}
$$

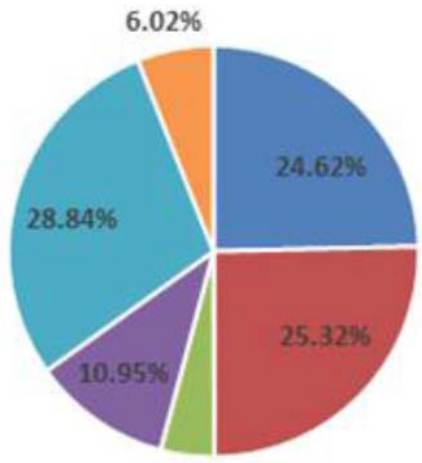

$4.25 \%$

b.

$$
\begin{aligned}
& \text { = RO Equipment } \\
& \text { = Equipment installation } \\
& \text { = Project management \& comissioning }
\end{aligned}
$$

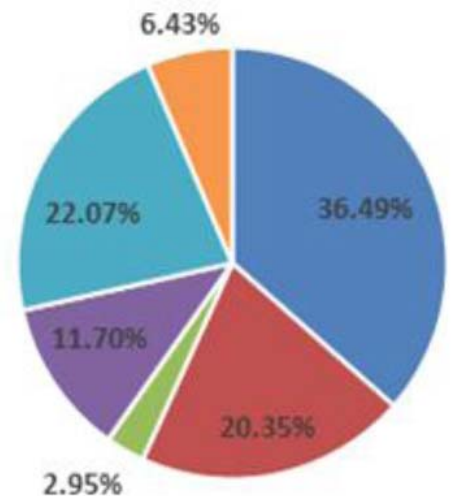

c.

Figure 12: Representative capital cost distribution in applications: a. WWRO; b. BWRO; c. WWRO (5). 
Table 4: Operating Cost Distribution in RO-Based Desalination Applications

\begin{tabular}{|c|c|c|c|}
\hline Subject & SWRO & BWRO & WWRO \\
\hline \hline Labor & $9 \%$ & $21 \%$ & $16 \%$ \\
\hline Electricity & $56 \%$ & $45 \%$ & $39 \%$ \\
\hline Membrane replacements & $6 \%$ & $6 \%$ & $15 \%$ \\
\hline Chemicals & $18 \%$ & $16 \%$ & $19 \%$ \\
\hline Parts and maintenance & $12 \%$ & $12 \%$ & $11 \%$ \\
\hline
\end{tabular}

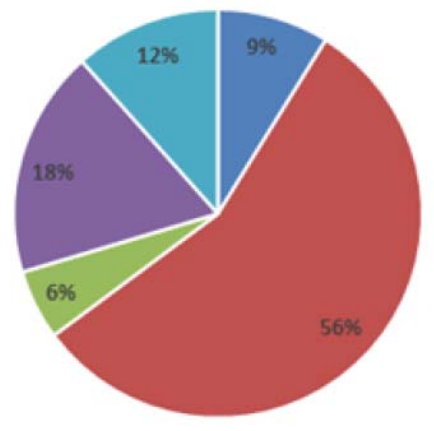

a.

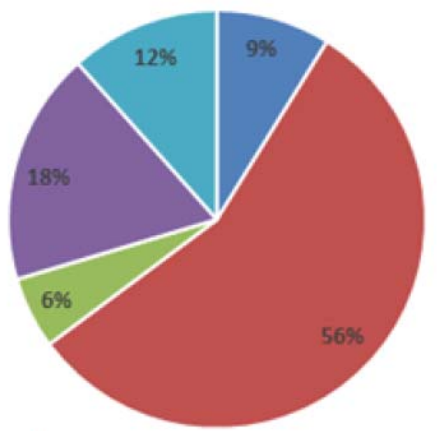

b.

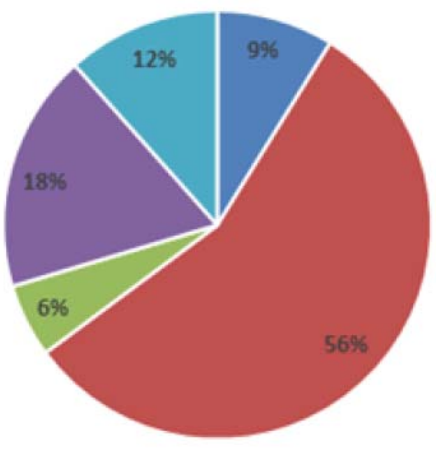

c.

Electricity

- Mmebrane replacements " Chemicals

= Parts am d maintenace

Figure 13: Representative operating cost distribution in applications: a. SWRO; b. BWRO; c. WWRO (5).

the major expense, especially in the SWRO but also in the other two processes. The chemicals used for fouling prevention and cleaning provide the second highest expense while labor, parts and maintenance follow.

\section{COST REDUCTION POTENTIAL}

Table 5 shows the different subjects taken in account when analyzing the three different desalination processes that may affect capital cost. The cost of site preparation and building depends on the available location for all categories. The design also depends on the companies involved, however, there is a potential in all systems for cost reduction in the case of standardization of system configurations. The intake is different in all the three categories, however, the disposal will probably go to the sea in all cases. Increased costs are expected if stricter environmental regulations will be enforced. This calls for improving our knowhow on real environmental effects.

Using better UF membranes and other techniques for fouling reduction may reduce the cost of feed water pretreatment in all categories. It is also important to integrate UF membranes in WW as a membrane bioreactor (MBR) process prior to WWRO. Cost reduction may affect $\mathrm{RO}$ trains with standardization of system configurations. However, the potential of reduction in $\mathrm{RO}$ membranes is low due to the existing trend of significant cost reduction in the past two decades.

Some potential for cost reduction through better understanding of corrosion potential and use of polymeric materials may affect the cost of piping and valves, as well as of high-pressure pumps and energy recovery devices. No changes are expected in the cost of electrical and motor control center (MCC), permeate post treatment, product storage and delivery, and membrane cleaning systems. Cost reduction of electronic components and standardization of process control programs may be expected.

Indirect capital costs, such as contingency, engineering and interest during construction, are not expected to change. However, owners' cost may change due to a possible reduction in the permit process for SWRO, and may increase in cases when 
Table 5: Potential for Reduction in Capital Costs in RO-Based Desalination Processes

\begin{tabular}{|c|c|c|c|}
\hline Cost Component & SWRO & BWRO & WWRO \\
\hline \multicolumn{4}{|c|}{ Direct Capital Costs } \\
\hline $\begin{array}{l}\text { Feed water } \\
\text { pretreatment }\end{array}$ & $\begin{array}{l}\text { Potential for cost reduction through } \\
\text { the development of effective } \\
\text { methods for membrane fouling } \\
\text { reduction. }\end{array}$ & $\begin{array}{l}\text { Potential for cost reduction } \\
\text { through the development of } \\
\text { effective methods for membrane } \\
\text { fouling reduction. }\end{array}$ & $\begin{array}{l}\text { Potential for cost reduction through } \\
\text { the development of effective methods } \\
\text { for membrane fouling reduction and } \\
\text { integration with the MBR process. }\end{array}$ \\
\hline Piping, valves & $\begin{array}{c}\text { Some potential for cost reduction } \\
\text { through better understanding of } \\
\text { corrosion potential and use of } \\
\text { polymeric materials. }\end{array}$ & $\begin{array}{l}\text { Some potential for cost reduction } \\
\text { through better understanding of } \\
\text { corrosion potential and use of } \\
\text { polymeric materials. }\end{array}$ & $\begin{array}{c}\text { Some potential for cost reduction } \\
\text { through better understanding of } \\
\text { corrosion potential and use of } \\
\text { polymeric materials. }\end{array}$ \\
\hline $\begin{array}{l}\text { High-pressure pumps } \\
\text { and energy recovery } \\
\text { devices }\end{array}$ & $\begin{array}{l}\text { Some potential for cost reduction } \\
\text { through better understanding of } \\
\text { corrosion potential and use of } \\
\text { polymeric materials. }\end{array}$ & $\begin{array}{l}\text { Some potential for cost reduction } \\
\text { through better understanding of } \\
\text { corrosion potential and use of } \\
\text { polymeric materials. }\end{array}$ & $\begin{array}{l}\text { Some potential for cost reduction } \\
\text { through better understanding of } \\
\text { corrosion potential and use of } \\
\text { polymeric materials. }\end{array}$ \\
\hline Electrical \& MCC & No changes expected & No changes expected & No changes expected \\
\hline $\begin{array}{c}\text { Permeate post } \\
\text { treatment, storage and } \\
\text { delivery }\end{array}$ & No changes expected & No changes expected & No changes expected \\
\hline \multicolumn{4}{|c|}{ Indirect Capital Costs } \\
\hline Contingency & No changes expected & No changes expected & No changes expected \\
\hline Engineering & $\begin{array}{l}\text { Some reduction due to } \\
\text { standardized design. }\end{array}$ & No changes expected & No changes expected \\
\hline Owners' cost & $\begin{array}{l}\text { Reduction possible with reduction in } \\
\text { length of permit process. }\end{array}$ & $\begin{array}{l}\text { Increase possible with stricter } \\
\text { regulation of concentrate } \\
\text { disposal. }\end{array}$ & No changes expected \\
\hline $\begin{array}{l}\text { Interest during } \\
\text { construction }\end{array}$ & No changes expected & No changes expected & No changes expected \\
\hline
\end{tabular}

stricter regulations of concentration disposal of all system are forced. More information on desalination costing may be found in $[6,7]$.

The potential related to a reduction in direct operating costs in RO-based desalination processes is summarized in Table 6. Slight improvements in pumping equipment efficiencies may cause some power reduction in future plants. Reduction in chemical usage due to better understanding and accumulated experience may reduce these expenses, especially regarding SWRO and WWRO. Membranes and cartridge replacements costs may be reduced slightly if better pretreatment and improved membranes will be developed.

Regarding indirect operating costs, the labor cost may be reduced slightly with a higher degree of 
Table 6: Potential for Reduction in Operating Costs in RO-Based Desalination Processes

\begin{tabular}{|c|c|c|c|}
\hline Operating Cost Component & SWRO & BWRO & WWRO \\
\hline \multicolumn{4}{|c|}{ Direct Operating Costs } \\
\hline Power & $\begin{array}{l}\text { Small reduction due to } \\
\text { slight improvement in } \\
\text { pumping equipment } \\
\text { efficiencies. }\end{array}$ & $\begin{array}{l}\text { Small reduction due to slight } \\
\text { improvement in pumping } \\
\text { equipment efficiencies. }\end{array}$ & $\begin{array}{l}\text { Small reduction due to slight } \\
\text { improvement in pumping equipment } \\
\text { efficiencies. }\end{array}$ \\
\hline Chemicals & $\begin{array}{l}\text { Some reduction due to } \\
\text { reduction in chemical } \\
\text { usage. }\end{array}$ & No significant changes & $\begin{array}{l}\text { Some reduction due to reduction in } \\
\text { chemical usage }\end{array}$ \\
\hline $\begin{array}{l}\text { Replacement of membranes } \\
\text { and cartridge filters }\end{array}$ & $\begin{array}{l}\text { Some reduction due to } \\
\text { reduction in membrane } \\
\text { fouling rate. }\end{array}$ & No significant changes & $\begin{array}{l}\text { Some reduction due to reduction in } \\
\text { membrane fouling rate. }\end{array}$ \\
\hline \multicolumn{4}{|c|}{ Indirect Operating Costs } \\
\hline Labor & $\begin{array}{l}\text { Some reduction due to } \\
\text { higher degree of process } \\
\text { automation. }\end{array}$ & No significant changes & No significant changes \\
\hline Spare parts and maintenance & $\begin{array}{l}\text { Some reduction due to } \\
\text { increased reliability of } \\
\text { system components. }\end{array}$ & No significant changes & $\begin{array}{l}\text { Some reduction due to increased } \\
\text { reliability of system components. }\end{array}$ \\
\hline Regulatory monitoring & $\begin{array}{l}\text { Some reduction due to } \\
\text { increase in monitoring } \\
\text { requirements. }\end{array}$ & No significant changes & $\begin{array}{l}\text { Some increase due to increase in } \\
\text { monitoring requirements. }\end{array}$ \\
\hline
\end{tabular}

operation experience, process automation and control. Better, increased reliability of spare parts may slightly reduce operating costs. Increased costs may be expected if increased monitoring will be required by regulations.

\section{SUMMARY}

RO-based desalination is a very reliable technology for augmenting potable water supply. The cost of major equipment and process consumables is similar worldwide; however, product water cost for the same application depends on the geographic/political location of the desalination plant. The variability of product water cost between various locations is the result of regulations, the permit process and local labor costs.

It is possible to slightly improve some of the parameters like higher flux of membranes while maintaining good rejection of salts, improve boron rejection, improve fouling prevention, better usage of energy, better UF pretreatment, all in order to reduce the energy consumption and the cost of water in order to provide better, affordable water.

The desalination process will continue to improve and some reduction in water cost can be expected. No major breakthroughs can be expected in the near future

\section{REFERENCES}

[1] Wilf M. The Guidebook to Membrane Desalination Technology. Reverse Osmosis, Nanofiltration and Hybrid Systems. Process, Design and Applications, with chapters by C. Bartels, L. Awerbuch, M. Mickley, G. Pearce and N. Voutchkov, Balaban Desalination Publications 2006.

[2] Wilf M. The Guidebook to Membrane Technology for Wastewater Reclamation. Wastewater Treatment, Pollutants, Membrane Filtration, Membrane Bioreactors, Reverse Osmosis, Fouling, UV Oxidation, Process Control, Implementation, Economics, Commercial Plants Design, with chapters by C. Bartels, D. Bloxom, J. Christopher, A. Festger, K. Khoo, V. Frenkel, J. Hudkins, J. Muller, G. Pearce R. Reardon and A. Royce, Balaban Desalination Publications (January 2010).

[3] Pankratz T. Compilation of published information in Water Desalination Report. No. 37 1999,No. 46, 2003,No. 7, 2004, No. 38, 2004. No. 48 2006, No. 9, 2011,No. 47, 2011, No. 49 2012,No. 30, 2013, N0.18 2015.

[4] Annon, Compilation of RO membrane elements performance data from different manufacturers on the internet.

[5] Annon, Information on desalination cost taken from different sources on the internet.

[6] Heather Cooley Newsha Ajami, Key Issues for Seawater Desalination in California: Cost and Financing November 2012 Editors Nancy Ross and Paula Luu, Pacific Institute.

[7] Watereuse Association Desalination Committee Seawater Desalination Costs White Paper, Water Reuse, https://www. watereuse.org/wp-content/uploads/2015/10/WateReuse_ Desal_Cost_White_Paper.pdf 